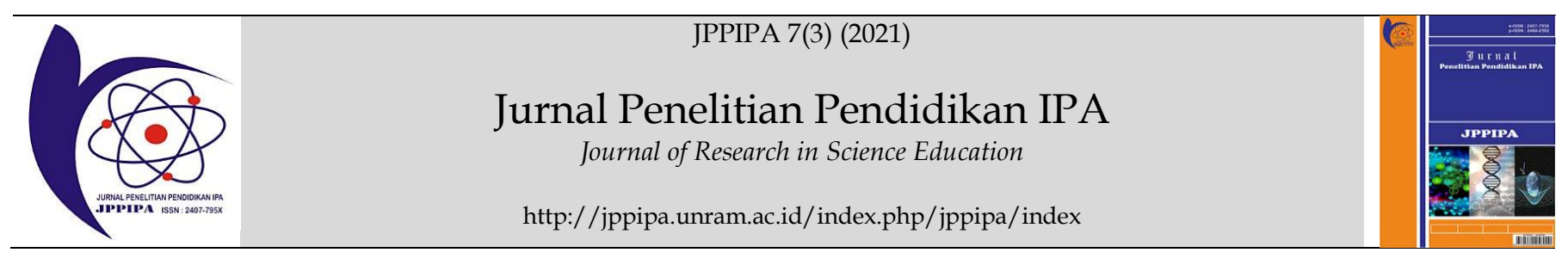

\title{
Development of Physics Learning Tools Model Discovery Learning on Momentum and Impulse Material
}

\author{
Isni Sahrianti ${ }^{*}$, Muhammad Taufik², I Wayan Gunada², Aris Doyan² \\ ${ }^{1}$ Physics Education, Mataram University, Lombok, West Nusa Tenggara, Indonesia \\ ${ }^{2}$ Master of Science Education Study Program, Postgraduate Program, Mataram University, Lombok, West Nusa Tenggara, Indonesia
}

DOI: $\underline{10.29303 / \text { jppipa.v7i3.580 }}$

\section{Article Info}

Received : Januari $14^{\text {th }}, 2021$

Revised : June 7th, 2021

Accepted: June 17th, 2021

\begin{abstract}
This study aims to produce a product in the form of a learning device with a model discovery learning on momentum and impulse material. This type of research used in this study is a research and development with a research model that was developed is the model $4 \mathrm{D}$ comprising the steps of define, the design, development, and Disseminate. Development is carried out until the limited trial stage by conducting validation trials up to the development stage and no distribution is carried out. The tools developed were syllabus, lesson plan, student worksheet, and test instruments on momentum and impulse materials. The results of the research are based on the data obtained and the results of the data analysis show that the results of the development of learning tools have a fairly valid value, this indicates that the physics learning tools using model's discovery learning on momentum and impulse materials are feasible to used.
\end{abstract}

Keywords: Model Discovery Learning; Momentum; Impuls

Citation: Sahrianti, I., Taufik, M., Gunada, I., \& Doyan, A. (2021). Development of Physics Learning Tools Model Discovery Learning on Momentum and Impulse Material. Jurnal Penelitian Pendidikan IPA, 7(3), 370-374. doi:https:// doi.org/10.29303/jppipa.v7i3.580

\section{Introduction}

Education is learning in the form of knowledge, skills, and habits carried out by a group of people from one generation to the next through teaching, training, or research. A learning can be taken in formal or nonformal forms. School is one of the places where a person can take education and be able to carry out a learning and teaching system. The education that is carried out certainly has an impact on students who learn, both in the form of skills, attitude and knowledge. From this statement, it can be said that school is a place to educate. Not only knowledge, but also skills which later can become a provision for students for life in the future. In addition, norms and good attitudes are also very necessary for everyone. The role of educators in this case is that teachers are certainly very influential in the school environment in educating students.
Syah, (2009) argues that educators must help students to develop and be able to adapt to their environment. The activity of teaching a subject matter is not only so that students master the knowledge (subject matter), but also so that they use their knowledge and skills in everyday life. In the current industrial era 4.0, science and technology are advancing. This progress is marked by various forms of applications that can be accessed via virtual (online). However, technology science is not only centered on social media, but can be used for educational facilities. One of the educations that can take advantage of current technology is Natural Sciences.

Natural knowledge in broad terms in relation to the Natural Sciences discipline is knowledge that is mathematical in nature and consists of several branches. Science studies about the phenomena and symptoms that exist in everyday life. One of the branches of science is physics. Oktaviani, et al (2018) stated that physics essentially has characteristics as a process, a product, 
and an attitude. Prayudi, et al. (2017) stated that physics as a collection of knowledge can be in the form of facts or theories. As a science, physics has an abstract concept, meaning that the concept comes from the imagination of scientists which can only be explained theoretically.

Physics lessons contain a lot of material, one of which is momentum and impulse. Momentum and impulse have a relationship known as the impulsemomentum theorem. In the material of momentum and impulse, many students do not yet understand in depth how the concept of how momentum and impulse occur. This is because students are less active when learning takes place. That is, students are passive in class, in other words only teachers who are active in learning activities. Students tend to only listen without analyzing what is obtained through the teacher's presentation.

Based on the results of observations at SMA Negeri 1 Gerung on several occasions with physics teachers and students before doing research, learning still tends to rely on the lecture method as the teaching material used by the teacher. In addition, students do not like physics lessons. Students assume that physics lessons are difficult lessons, both for memorizing formulas and when working on problems. Students also find it difficult to understand the concepts explained by the teacher because of the limited materials used by the teacher at the time of learning. Students tend to be given material from the beginning of the lesson to the end, this is certainly less effective. The teacher as a facilitator, must be able to foster curiosity in students so that students can easily understand the concepts in physics. Therefore, we need a learning model that can support this, one of which is the model discovery learning.

The learning model is the whole series used by the teacher in presenting material to be delivered to students in the classroom. The learning model that the researcher wants to use is the model discovery learning with several reasons that have been stated previously, so that the mastery of concepts in students can master and understand the material presented by the teacher. Model discovery learning is a learning model by not giving the material in final form, meaning that learners are required to search for and discover for themselves what is being learned. In this model, students are required to be more creative, independent and creative with existing problems (Qurniati, et al. 2015). Learning Discovery model is a learning model that is considered suitable for learning physics. Physics as a process of investigation includes ways of thinking, attitudes, and steps for scientific activities to obtain scientific science products, for example, observation, measurement, formulating and testing hypotheses, collecting data, experimenting, and predicting (Kemendikbud, 2015).

Sari, et al. (2016) stated that discoverydiscovery learning is-based learning. Learning Discovery is a series of learning activities where the teacher presents teaching materials not in a final form, but provides an opportunity to seek and find their own concepts on the material being studied. According to Winataputra in Damayanti, et al. (2016), discovery learning consists of six stages, namely: (1) stimulus, (2) problem statements (3) data collection, (4) data processing, (5) verification, and (6) generalization. Discovery learning emphasizes higher-order thinking, this is one of the abilities developed when studying physics. Pujriyanto, (2005) states that technological developments with the use of instructional media are also very important for physics, namely in delivering material. In the era of the industrial revolution 4.0, of course, the development of science and technology is very much needed. Therefore, teachers must also be able to make good use of the development of science and technology in teaching and learning activities. The learning tools contained in the model discovery earning include videos, syllabus, lesson plans with a special syntax for model's discovery learning, student worksheet and test instruments. Physics learning with model's discovery learning tools allow students to think which leads to understanding the concepts contained in syntax, discovery learning the fourth phase of namely the data processing phase. Activities in this phase can improve the mastery of physics concepts in trainees.

Seeing the conditions of the learning process today, in view of the need for learning tools that create students to learn to find their own knowledge and can be used for pursuits online. Therefore, researchers develop learning tools that have such characteristics. The learning tools include syllabus, lesson plans, student worksheet, and test instruments.

Based on the description above, the researcher developed a model of physics discovery learning in the material of momentum and impulse. The use of models is discovery learning used because in discovery learning, students are directed to learn more independently without demanding to always be explained first. The model of physics learning device discovery learning and the existence of learning videos, it is hoped that students will understand and understand the material momentum and impulses.

\section{Method}

The type of research used in this research is research and development 4D models (Define, Design, Develop, and Disseminate). Fatmawati, (2016) defines development research as a process or steps to develop a new product or improve an existing and accountable product. 
In the definition phase (define) conducted a preliminary analysis of the learning activities conducted in SMA Negeri 1 Gerung, analysis of the contents of teaching materials task outline of Core Competence and the Basic Competency in accordance with the curriculum of 2013. Analysis of the main concepts which will be taught and systematically compile and detail the relevant concepts, as well as the formulation of learning objectives.

The second stage is design by selecting the format of learning tools including the syllabus format, the lesson plan, student worksheet, and test instruments, as well as the design of learning tools.

The next stage is the stage of development to produce a learning device which has been revised based on input from experts, which is a device by validator expert validation and testing is limited by physical education students, the University of Mataram.

The last stage, namely the dissemination, aims to disseminate the product in the form of the developed physics learning device. The deployment stage is the final stage in the $4 \mathrm{D}$ model development research. Research on the development of learning tools with model's discovery learning uses a research and development design. Azhari et al. (2018) states that development research has 4 levels of difficulty, namely "researching without making and testing products, without researching only testing existing products, researching and developing existing products, researching and creating new products". This research was not carried out in the dissemination stage, which only carried out research up to the stage develop.

In research, tools are needed to collect data so that a research result will be found. To collect these data, a research instrument is needed. The research instruments that will be used in this research are the syllabus, the lesson plan, the student worksheet, and the test instrument.

Validation sheets are used to obtain learning device assessment data by validators, as well as get suggestions for improving learning tools that have been developed. The research data were collected using expert validation sheets and data analysis using a Likert scale. The formula for calculating the percentage is as follows:

$$
P=\frac{f}{N} \times 100 \% \text {. }
$$

Information:

$\mathrm{f}=$ score obtained

$\mathrm{N}=$ total frequency/maximum score

$\mathrm{P}=$ percentage number

The validation sheet for the use of 4 selected products according to the question content. Changing the results of the assessment from letters to scores with the provisions using the Rating Scale scale which can be seen in table 1 below:

Table 1. Assessment Score against Choice of Answer

\begin{tabular}{lll}
\hline No & Options & Score \\
\hline 1 & Good & 4 \\
2 & Poor & 3 \\
3 & Fairly Good & 2 \\
4 & Not Good & 1 \\
\hline & & (Latifah et al. 2016).
\end{tabular}

The validation questionnaire uses 4 choices according to the question content. The percentage data obtained is then converted into the criteria for the validity of the learning devices listed in Table 2 below.

Table 2. Criteria for the Validity of Learning Devices

\begin{tabular}{|c|c|c|}
\hline No & Percentage of $(\%)$ & Validity criteria \\
\hline 1 & $85.01-100$ & $\begin{array}{l}\text { Very Valid, or can be used } \\
\text { without revision }\end{array}$ \\
\hline 2 & $70.01-85.00$ & $\begin{array}{l}\text { Quite valid, or can be used } \\
\text { but needs to be revised }\end{array}$ \\
\hline 3 & $50.01-70.00$ & $\begin{array}{l}\text { Less valid, it is } \\
\text { recommended not to use it } \\
\text { because it needs major } \\
\text { revision. }\end{array}$ \\
\hline 4 & $01.00-50.00$ & $\begin{array}{l}\text { Not valid or may not be } \\
\text { used }\end{array}$ \\
\hline
\end{tabular}

(Anggreini et al. 2019).

\section{Result and Discussion}

The aim of this research is to know the feasibility of the device developed by using model discovery learning on momentum and impulse material. The results of this study consist of the results of the model research stages, 4D namely the define stage, design, develop, and disseminate.

\section{The Define}

The define stage is the initial stage which aims to obtain information in the form of problems that arise during learning, the learning methods used by teachers and other supporting media and review the curriculum used. At this stage, an initial analysis is carried out to examine the characteristics of students, and the problems in learning physics that arise during learning. In the initial analysis stage, the activities carried out were observation at SMA Negeri 1 Gerung. Observation aims to obtain an overview of the state of the school related to the development research that will be carried out. Furthermore, a task analysis is carried out which aims to determine the content in a lesson by detailing the content of the teaching material in an outline of the Core Competencies and Basic Competencies in accordance with the revised 2013 Curriculum. In this study, the 
learning tools developed were learning at Basic Competencies 3.10 and 4.10, namely momentum and impulse. Besides that, important concepts are identified, systematically arranges and details relevant concepts and links one concept to another to form a concept map. The last one is to formulate learning objectives that describe the process and results to be achieved.

\section{Design Stage}

The next stage is the design stage in which the researcher designs the learning tools and research instruments that are developed. The products developed are learning tools that are arranged including syllabus, lesson plans, student worksheet, and test instruments. The research instruments used were validation sheets and student response questionnaires.

\section{Development Stage}

The develop stage is the stage to produce a product development which is carried out in several steps. At this stage, an expert validator is assessed. The results of this development stage are qualitative data and quantitative data obtained from the assessment and suggestions of expert validators. The validation sheet is in the form of an assessment questionnaire and is filled in by expert validators, including 3 physics education lecturers and 3 physics teachers regarding the development of devices made by researchers. The physics education lecturer who became the expert validator was the physics education lecturer at the FKIP University of Mataram. The 3 teachers became expert validators, namely 1 SMA Negeri 3 Mataram physics teacher and 2 SMA Negeri 1 Gerung teachers.

Based on the results of calculations using ascale Likert, the obtained average validity value of each learning device from expert validators can be seen in Table 3 below:

Table 3. Validity of Device Validator

\begin{tabular}{lll}
\hline No & Tool & Validity value per criterion $(\mathrm{P})$ \\
\hline 1 & Syllabus & $84.72 \%$ \\
2 & Lesson Plan & $85.83 \%$ \\
3 & student worksheet & $83.93 \%$ \\
4 & Test instrument & $84.03 \%$ \\
\hline
\end{tabular}

Based on the validity results in the table above, it can be said that the average validity of the learning tools developed falls into the very good category.

\section{Conclusion}

Based on the data obtained and the results of data analysis, it is concluded that the physics learning device using the model discovery learning on the momentum and impulse material has sufficient valid criteria, this shows that the device with themodel discovery learning on the momentum and impulse material is suitable for use in learning.

\section{References}

Anggreini, E., Zulkarnain., \& Ariawan, R. (2019). Pengembangan Perangkat Pembelajaran Matematika dengan Problem Based Learning (PBL) pada Materi Sistem Persamaan Linear Tiga Variabel di Kelas X SMK Yahri Terpadu Pekanbaru. Aksiomatik. 7(1):35-40. Retrieved from: https://journal.uir.ac.id/index.php/AKS/article /view/2389 [Indonesian]

Azhari, M.V., Nurani, A.S., \& Patriasih, R. (2018). Pengembangan Template Media Pembelajaran Sebagai Sarana Presentasi Mahasiswa Dalam Mata Kuliah Seminar Tata Boga. Media Pendidikan, Gizi dan Kuliner. 7(1): 55-66. doi: https://doi.org/10.17509/boga.v7i1.11597 [Indonesian]

Damayanti, S., Mahardika, I.K., \& Indrawati, I. (2016). Penerapan Model Discovery Learning Berbantuan Media Animasi Macromedia Flash Disertai LKS yang Terintegrasi dengan Multirepresentasi Dalam Pembelajaran Fisika. Jurnal Pembelajaran Fisika. 4(4): 357-364. Retrieved from: https://jurnal.unej.ac.id/index.php/JPF/article/ view/3090 [Indonesian]

Fatmawati, A. (2016). Pengembangan Perangkat Pembelajaran Pencemaran Lingkungan menggunakan Model Pembelajaran Berdasarkan Masalah untuk SMA Kelas X. EduSains, 4(2), 94103. Retrieved from: https://e-journal.iainpalangkaraya.ac.id/index.php/edusains/article/ view/512 [Indonesian]

Kemendikbud. (2015). Peraturan Menteri Pendidikan dan Kebudayaan Republik Indonesia Nomor 53 tahun 2015 tentang Penilaian Hasil Belajar oleh Pendidik pada Pendidikan Dasar dan Menengah. Jakarta: Depdikbud. [Indonesian]

Latifah, S., Setiawati, E., \& Basith, A. (2016). Pengembangan Lembar Kerja Peserta Didik (LKPD) Berorientasi Nilai-Nilai Agama Islam Melalui Pendekatan Inkuiri Terbimbing Pada Materi Suhu dan Kalor. Jurnal Ilmiah Pendidikan Fisika Al-BiRuNi. 5(1): 43-51. doi: https://doi.org/10.24042/jpifalbiruni.v5i1.104 [Indonesian]

Oktaviani, D., Harjono, A., \& Gunada, I. (2018). Penguasaan Konsep Usaha Dan Energi Peserta Didik Kelas X Dengan Model Pembelajaran Ekspositori Berbantuan Organizers. Jurnal Pendidikan Fisika dan Teknologi, 4(2), 192-201. doi:http://dx.doi.org/10.29303/jpft.v4i2.821. [Indonesian] 
Prayudi, L., Sahidu, H., \& Gunawan, G. (2017). Pengaruh Penggunaan Media Audiovisual Dengan Pendekatan Metakognitif Berbasis Masalah Terhadap Hasil Belajar Fisika Siswa Kelas XI IPA Di SMAN 1 Gerung Tahun Pelajaran 2016/2017. Jurnal Pendidikan Fisika dan Teknologi, $3(1)$, 55-60. doi:http://dx.doi.org/10.29303/jpft.v3i1.324. [Indonesian]

Pujriyanto. (2005). Strategi Pemanfaatan Animasi Sebagai Alat dan Media Pembelajaran. Majalah Ilmiah Pembelajaran. 2(1): 182-198. [Indonesian]

Qurniati, D., Andayani, Y., \& Muntari, M. (2015). Peningkatan Keterampilan Berpikir Kritis Melalui Model Pembelajaran Discovery Learning. Jurnal Penelitian Pendidikan IPA. 1(2): 59-69. doi:https://doi.org/10.29303/jppipa.v1i2.20 [Indonesian]

Sari, P., Gunawan, G., \& Harjono, A. (2017). Penggunaan Discovery Learning Berbantuan Laboratorium Virtual pada Penguasaan Konsep Fisika Siswa. Jurnal Pendidikan Fisika dan Teknologi, 2(4), 176-182. doi:http://dx.doi.org/10.29303/jpft.v2i4.310. [Indonesian] 